\title{
Recovery of Attorney Fees from Third Party Tortfeasors
}

American legislatures generally have chosen not to allow recovery of attorney fees to the prevailing party in litigation. This "American rule" has always been subject to exceptions, and their number has steadily increased. In 1963, the California Supreme Court, in Prentice v. North American Title Guarantee Corp. , ${ }^{1}$ appeared to create another minor exception by allowing recovery of attorney fees to a plaintiff who, through the negligent tort of the defendant, had been required to bring a quiet title action against a third party. Although this "third party" exception was originally construed quite narrowly, recent California decisions have greatly expanded its scope, an expansion that could have a significant impact on tort litigation in California.

This Comment will briefly examine the policies supporting the American rule and some of the judicial exceptions to the rule. Prentice will be analyzed both in terms of its factual setting and its ambiguous language. Finally, the Comment will examine the constraints placed on the third party exception by the policies underlying the American rule.

\section{I}

\section{THE AMERICAN Rule on AtTORNEy Fees}

English courts have long been authorized to award attorney fees to the prevailing party, ${ }^{2}$ and most countries ${ }^{3}$ have followed the English practice. ${ }^{4}$ In America, however, the common law adoption of the English rule has generally been abrogated by statute. ${ }^{5}$ The American rule provides instead

1. 59 Cal. 2d 618, 381 P.2d 645, 30 Cal. Rptr. 821 (1963).

2. The Statute of Gloucester, $6 \mathrm{Edw}$. I, c. 1 (1275), awarded costs to successful plaintiffs at law; successive statutes in 1531 (23 Henry VIII, c. 15, § 1 (1531-32)) and 1607 (4 Jac. I, c. 3) awarded them to successful defendants. $3 \mathrm{~W}$. BLACKSTONE, COMMENTARIES *399-400. In 1875, the common law rule was changed to conform to the chancery rule that costs be in the discretion of the court., Goodhart, Costs, 38 YALE L.J. 849, 851-854 (1929).

3. See Ehrenzweig, Shall Counsel Fees Be Allowed?, 26 CaL. ST. B.J. 107, 109-110 (1951); Note, Attorney's Fees: Where Shall the Ultimate Burden Lie?, 20 VAND. L. REv. 1216, 1223-24 (1967).

4. The rationale for recovery of fees is simply that every wrong should have a remedy. As proponents of the English rule have argued, it is strange that a man run down on the public highway can recover his doctor's bill, but not his lawyer's bill. Judicial Council of Massachussets, First Report, 11 MAss. L.Q. 7, 64 (1925), discussed in Ehrenzweig, Reimbursement of Counsel Fees and the Great Society, 54 CALIF. L. REV. 792, 794 (1966). Under fee arrangements prevalent in America, many wrongs will have only two-thirds of a remedy, with the remainder of plaintiffs' recovery going for attorney fees.

5. See Goodhart, supra note 2, at 873 . 
that, in the absence of some statutory right or contractual provision, each party to litigation must bear its own attorney fees. ${ }^{6}$ Proponents of this rule argue that it ensures every person a day in court by limiting the risks of litigation; meritorious claims and defenses are less likely to be raised if the result of losing means bearing the burden of the other party's attorney fees, as happens with the English rule. ${ }^{7}$ Since each party knows that it will bear its own costs, the American rule is thought to foster economy by discouraging unnecessary legal expense. ${ }^{8}$ Finally, proponents of the American rule argue that attorney fees are an unacceptably remote consequence of the tortious act. ${ }^{9}$

The American rule has nonetheless been subject to a variety of exceptions, ${ }^{10}$ the bulk of them fashioned by legislatures. ${ }^{11}$ The United States

6. E.g., Alyeska Pipeline Serv. Co. v. Wilderness Soc'y, 421 U.S. 240, 246-55 (1975); Griggs v. Board of Trustees, 61 Cal. 2d 93, 389 P.2d 722, 37 Cal. Rptr. 194 (1964). See generally C. MCCORMICK, HANDBOOK ON THE LAW OF DAMAGES 234-36 (1935).

California, for example, has codified the rule in Code of Civil Procedure $\S 1021$ : "[Unless] specifically provided for by statute, the measure and mode of compensation of attorneys and counsellors at law is left to the agreement, express or implied, of the parties . . ." (West 1955). Professor Ehrenzweig, in tracing $\S 1021$ to its origins in $\S 258$ of the New York Code of 1848 , suggests that the origins of the American rule lie more in chance than in reason:

"[t]he California rule (conforming to the laws of most other states of the Union and contrary to the laws of most other countries) under which the costs recoverable by the prevailing party do not include counsel fees, is not founded on some age-old principle of the common law or a peculiar psychology of the American people; but the result of a more or less accidental statutory history . . . due to the simple fact that the New York legislature in 1848, in attempting to perpetuate what it considered a sound legal rule of recovery of attorneys' fees by the prevailing party, made the fatal mistake of fixing the amount recoverable in dollars and cents rather than in percentages of the amount recovered or claimed."

Ehrenzweig, Shall Counsel Fees Be Allowed?, supra note 3, at 110-13.

7. See Cal. Senate Comm. on Judiciary, Interim Hearing on Attorney's Fees to the Prevailing Party and Attorney's Fees In Class ACtions, 5, 19, 43 (1974) thereinafter cited as INTERIM HEARING]; 1 S. SpEISER, ATtORNEY FEeS \& 12:3, at 467, and at 476 n. 27 (1973); Satterthwaite, Increasing Costs to be Paid by Losing Party, 46 N.J.L.J. 133 (1923), discussed in Goodhart, supra note 2 , at 877.

8. Too often, attorney fee awards are not the icing on the cake; they are the cake. See INTERIM HEARING, supra note 7, at 64.

9. See generally C. MCCORMICK, supra note 6, 234, 255; Avilla, Shall Counsel Fees Be Allowed?, 13 CAL. ST. B. J. 42 (1938); Ehrenzweig, Shall Counsel Fees Be Allowed?, supra note 3; Goodhart, supra note 3; Stirling, Attorney's Fees: Who Should Bear the Burden?, 41 CAL. ST. B.J. 874,877 n.6 (1966).

10. It has been subject to a barrage of critical commentary as well. See, e.g., C. MCCORMICK, supra note 6; 1 SPEISER, supra note 7, § 12.8; Ehrenzweig, Shall Attorney Fees Be Allowed?, supra note 3; Greenberger, The Cost of Justice: An American Problem, An English Solution, 9 VILL. L. Rev. 40 (1964); Kuenzel, The Attorney's Fee: Why Not a Cost of Litigation?, 49 Iowa L. Rev. 75 (1963); McLaughlin, The Recovery of Attorney's Fees: A New Method of Financing Legal Services, 40 Ford. L. REV. 761 (1972); Posner, An Economic Approach to Legal Procedure and Judicial Administration, 2 J. LEGAL STUD. 399, 437-38 (1973); Stirling, supra note 9; Stoebuck, Counsel Fees Included in Costs: A Logical Development, 38 Colo. L. Rev. 202 (1966); Note, 65 MrCH. L. Rev. 593 (1967); Comment, Court Awarded Attorney's Fees and Equal Access to the Courts, 122 U. PA. L. REv. 636, 648-55 (1974); Note, Attorney's Fees: Where Shall the Ultimate Burden Lie?, supra note 3.

11. The recovery of attorney fees is currently mandated by 44 federal statutes and permitted by an additional 52 . California likewise has 91 statutes that presently require fee 
Supreme Court has suggested that legislatures alone have the privilege of creating new exceptions; ${ }^{12}$ California sharply rejects this view. ${ }^{13}$ Certainly, although no American jurisdiction allows an unfettered judicial discretion to award attorney fees, there remain, in both the state and the federal systems, half a dozen major common law exceptions to the American rule. For example, attorney fees can generally be shifted when a party's efforts have created or protected a common fund ${ }^{14}$ or have advanced the public interest as a private attorney general. ${ }^{15}$ Courts have also allowed recovery of fees from one who has engaged in improper litigation tactics by bringing or defending an action in bad faith, wantonly, or for "oppressive reasons.", 16 This bad faith rationale has been extended to allow recovery of fees as tort damages from those guilty of malicious prosecution, malicious abuse of process, or false imprisonment. ${ }^{17}$ Recovery of fees in these situations serves to deter abuse of the judicial process and to provide judicial control of such abuse. Indeed, imposition of fees may prove to be the only punishment

awards and 47 statutes that permit them. These statutes are listed in Calif. ConTinuing Educ. of the Bar., AtTorneys' Fees, Selected Resource Materials 7-37 (1976).

The statutory exceptions have been based on a variety of empirical policies rather than any unitary principle. For example, legislatures have responded to such concerns as administrativc economy, as in the Clayton Act, 15 U.S.C. $\S 15$ (1970), in which fee awards serve as an incentive to private enforcement of the antitrust laws, allowing a corresponding reduction of personnel in the Department of Justice. Other examples are a desire to redress imbalances of power between litigants, as in the Fair Labor Standards Act, 29 U.S.C. $\$ 216(\mathrm{~b})(1970)$, or a demand that the prosecution and punishment of particularly antisocial acts be facilitatcd through fee shifting, as in the Federal Water Pollution Control Act, 33 U.S.C. $§ 1365$ (d) (1975). Cf. Alyeska Pipeline Serv. Co. v. Wilderness Soc'y, 421 U.S. 240, 264 (1975) (analysis of fec awards in antitrust and civil rights areas).

12. Granting or withholding fee awards " [is] a policy matter that Congress has reserved for itself. Since the approach taken by Congress to this issue has been to carve out specific exceptions to a general rule that federal courts cannot award attorneys' fees . . . those courts are not free to fashion drastic new rules." Alyeska Pipeline Serv. Co. v. Wilderness Soc'y, 421 U.S. 240, 270 (1975). Cf. Ex parte Kyle, 1 Cal. 331, 332 (1850) (similar deference to legislature on attorney fees).

13. See note 40 infra and accompanying text.

14. The departure of this exception from the American rule is supposedly lessened by the declaration that such awards are "as between solicitor and client" rather than "between party and party." Sprague v. Ticonic Nat'l Bank, 307 U.S. 161, 165 (1939). The doctrine has been expanded to include situations in which the effect of suit is the same as if a fund were created, as when litigation confers a "substantial benefit" on members of an ascertainable class. Mills v. Electric Auto-Lite Co., 396 U.S. 375 (1970).

15. While this exception has been withdrawn in federal suits, Alyeska Pipeline Serv. Co. v. Wilderness Soc'y, 421 U.S. 240 (1975), California has recently reaffirmed its adherence to it. Serrano v. Priest (Serrano III), 20 Cal. 3d 25, 569 P.2d 1303, 141 Cal. Rptr. 315 (1977).

16. This is to apply, however, only in exceptional cases and for "overriding considerations of justice." See generally 6 MOORE's FEDERAL PRACTICE I-54.77[2], at 1709-12 (2d ed. 1953). Although California courts have regularly awarded attorney fees in situations that clearly take their rationale from the bad faith exception, see text at notes 17-20 infra, the California Supreme Court has explicitly reserved the question of whether California courts have the discretion to award attorney fees to one party as a sanction for the vexatious and oppressive conduct of another party or its counsel. D'Amico v. Board of Med. Examiners, 11 Cal. 3d 1, 27, 520 P.2d 10, 29, 112 Cal. Rptr. 786, 805 (1974).

17. See RESTATEMENT (SECOND) OF TORTS $\$ \S 670,671,681,682$ (1977). 
available against such tortfeasors in those situations where plaintiffs lack claims for compensatory or punitive damages.

Where bad faith by a third party causes a person to be involved in litigation with others, courts have regularly allowed a third party exception, whereby the claimant can recover the attorney fees incurred in that litigation from the third party tortfeasor. ${ }^{18}$ The bad faith involved in the great majority of these decisions has been obvious and substantial, occurring where such wilful torts as fraud, conversion, or tortious removal from office had been alleged. ${ }^{19}$

The bad faith exception, however, has sometimes been extended to a questionable degree. Recovery of fees has, for example, been allowed in slander of title actions ${ }^{20}$ on the ground that, like malicious prosecution, such torts are "based on conduct calculated to result in litigation." "21 In slander of title actions, however, there is no inherent abuse of the judicial process that requires special judicial control. The deterrent effect of a fee award is also unnecessary since one who slanders a title may be held directly liable to the property owner for civil damages. The policy basis for allowing a bad faith exception is further attenuated when quiet title rather than slander of title is the basis of the litigation, for quiet title actions require no bad faith on the part of the third-party tortfeasor. This, however, was precisely the fact situation under which the California Supreme Court approved a fee award in Prentice. The problems arising from this decision are a result of its possibly inadvertent extension of the third party exception to include fee awards in actions based on negligent torts.

18. Weems v. George, 54 U.S. (13 How.) 190 (1851); Wilshire Oil Co. v. Riffe, 409 F.2d 1277 (10th Cir. 1969); Seaboard Sur. Co. v. Permacrete Constr. Corp., 130 F. Supp. 184 (E.D. Pa. 1954), aff'd, 221 F.2d 366 (3d Cir. 1955); Fidelity \& Cas. Co. v. J.D. Pittman Tractor Co., 244 Ala. 354, 13 So. 2d 669 (1943); Treat v. Nowell, 37 Ariz. 290, 294 P. 273 (1930); International State Bank v. Trinidad Bean \& Elevator Co., 79 Colo. 286, 245 P. 489 (1926); Murphy v. O'Donnell, 63 A.2d 340 (App. D.C. 1948); Himes v. Kleighblingher, 14 MI. 469 (1853); First Nat'l Bank v. Williams, 62 Kan. 431, 63 P. 744 (1901); Indiana Nat'l Life Ins. Co. v. Butler, 186 Ky. 81, 215 S.W. 949 (1919); McGaw v. Acker, Merrall \& Condit Co., 111 Md. 153, 73 A. 731 (1909); Boston \& Atl. R. Co. v. Richardson, 135 Mass. 473 (1883); In re State Farm Mut. Auto. Ins. Co., 50 Mich. App. 71, 212 N.W.2d 821 (1973); Bergquist v. Kreidler, 158 Minn. 127, 196 N.W. 964 (1924); Myers v. Adler, 188 Mo. App. 607,176 S.W. 538 (1915); Hubbard v. Gould, 74 N.H. 25, 64 A. 668 (1906); Dinkle v. Denton, 68 N.M. 108, 359 P.2d 345 (1961); Slingerland v. Bennett, 66 N.Y. 611 (1876); Security State Bank v. W. R. Johnston \& Co., 204 Okla. 160, 228 P.2d 169 (1951); Addy v. Bolton, 257 S.C. 28, 183 S.E.2d 708 (1971); Du Pratt v. Black Hills Land \& Abstract Co., 81 S.D. 637, 140 N.W.2d 386 (1966); Pacific Coast Title Ins. Co. v. Hartford Ins. Co., 7 Utah 2d 377, 325 P.2d 406 (1958); Hiss v. Friedberg, 201 Va. 572, 112 S.E.2d 871 (1960); Curtley v. Security Sav. Soc'y, 46 Wash. 50, 89 P. 180 (1907); Thomason v. Mosrie, 134 W. Va. 634, 60 S.E.2d 699 (1950); Weinhagen v. Hayes, 179 Wis. 62, 190 N.W. 1002 (1922).

19. See. Annot., 4 A.L.R. 3d 270 (1965); Restatement of TorTs $§ 914$ (1939).

20. See Restatement OF TORTS $\S 914$ (1939); RESTATEMENT (SECOND) OF TORTS $\S 633$ (b) (1977).

21. Contra Costa County Title Co. v. Waloff, 184 Cal. App. 2d 59, 68, 7 Cal Rptr. 358, 363 (1st Dist. 1960). 


\section{II}

\section{THE THIRD PARTY EXCEPTION}

\section{A. Prentice}

In Prentice v. North American Title Guarantee Corp., 22 a vendor of real property sought to quiet title against the vendee and, in the same action, to recover attorney fees from the escrow agent whose negligence made the action necessary. ${ }^{23}$ The California Supreme Court sustained the award for the vendor's fees, holding that:

A person who through the tort of another has been required to act in the protection of his interests by bringing or defending an action against a third person is entitled to recover compensation for the reasonably necessary loss of time, attorney's fees, and other expenditures thereby suffered or incurred. ${ }^{24}$

The breadth of Prentice's language is matched by the brevity of its analysis, making it difficult to determine the intended scope of the third party exception. In view of the authorities cited ${ }^{25}$ and the summary nature of the opimion, it is probable that Prentice merely intended to create a limited exception to the American rule by allowing fee awards in quiet title actions. ${ }^{26}$ There is, however, serious question whether even this slight expansion is doctrinally justifiable. As with slander of title actions, there is no inherent abuse of the judicial process in quiet title actions and therefore no need for courts to use fee awards to maintain control. Since malice is not a requisite element of quiet title actions, there is little justification for awarding attorney fees as a punitive measure. In the absence of intentional wrongdoing,

22. 59 Cal. 2d 618, 381 P.2d 645, 30 Cal. Rptr. 821 (1963).

23. The vendor had subordinated his mortgage interest in favor of the buyers' construction loan, but the buyers misappropriated the proceeds, and the vendor claimed that the agent had been negligent in closing the deal. $59 \mathrm{Cal} .2 \mathrm{~d}$ at 619, $381 \mathrm{P} .2 \mathrm{~d}$ at $645,30 \mathrm{Cal}$. Rptr. at 821 .

24. Id. at 620,381 P.2d at 647, $30 \mathrm{Cal}$. Rptr. at 823 . The California authorities citcd by Prentice as allowing such a third-party exception are Stevens v. Chisholm, 179 Cal. 557, 564, 178 P. 128, 131 (1919) (malicious prosecution); Nelson v. Kellogg, 162 Cal. 621, 623, 123 P. 1115,1116 (1912) (false imprisonment); Contra Costa County Title Co. v. Waloff, 184 Cal. App. 2d 59, 68, 7 Cal. Rptr. 358, 363 (1st Dist. 1960) (quiet title); and Estate of Williamson, 150 Cal. App. 2d 334, 341, 310 P. 2d 77, 82 (1st Dist. 1957) (statutory authorization of fees for violation of Probate Code). Waloff, in particular, explicitly equates quiet title with the traditional slander of title exception that allows recovery of attorney fees from the third party tortfeasor as an element of damages caused by the third party's bad faith. See text at note 20 supra.

25. In addition to California cases, Prentice cites 15 AM. JuR. Damages $\$ 144$, at 552 (1938); 25 C.J.S. Damages $\$ 50$ c, at 534 (1941); and RESTATEMENT OF TORTS $\$ 914$ (1939). Although the court does not acknowledge the fact, each of these sources mentions the third party exception only with respect to cases involving intentional torts or torts characterized by bad faith.

26. Prior to Prentice, the exception was occasionally allowed where the negligence led to a quiet title action, presumably because "quiet title" looked superficially similar to "slander of title," where third party fee awards have generally been allowed. The cases themselves do not make this clear, though they typically refer to fraud or breach of contract as justification for the award. See Barnett v. Montgomery, 22 Ky. (6 T.B. Mon.) 327 (1827); Murphy v. Fidelity Abstract \& Title Co., 114 Wash. 77, 194 P. 591 (1920). 
sufficient deterrence is probably provided by the defendant's own attorney fees.

On the other hand, the very absence of explicit qualifications to the exception necessarily leaves its scope uncertain. The language chosen in Prentice for delimiting cases in which the third party exception should apply suggests an expansive application of the exception. The opinion indicates that fees are to be awarded where "a defendant has wrongfully made it necessary for a plaintiff to sue a third party" because attorney fees in such cases are damages rather than attorney fees. ${ }^{27}$ This logic is questionable. Whether a tortfeasor wrongfully makes it necessary for a plaintiff to sue him or makes it necessary for a plaintiff to sue someone else, an innocent party has been compelled to incur attorney fees in order to protect his rights. To label the expense as "fees" in one case and "damages" in the other fails logically to distinguish the situations. ${ }^{28}$ Read broadly, Prentice could thus be taken to have opened the door to widespread awards of fees under the rubric of damages.

The appellate response to Prentice has reflected, rather than resolved, the ambiguities of that decision. The case was originally read very narrow$1 y^{29}$ and applied to quiet title and slander of title actions only. ${ }^{30}$ In 1972 ,

27. The court rejected the agent's claim that Code of Civil Procedure $\S 1021$ barred such an award. Admitting that the statute "undoubtedly prohibits the allowance of attorney fees against a defendant in an ordinary two-party lawsuit," the court held that it did not apply to third party situations because in such a case "we are not dealing with 'the measure and mode of compensation of attorneys' but with damages wrongfully caused by defendant's improper actions." 59 Cal. $2 \mathrm{~d}$ at $620-21,381$ P.2d at $647,30 \mathrm{Cal}$. Rptr. at 823.

28. "Every person who suffers detriment from the unlawful act or omission of another, may recover from the person in fault a compensation therefor in money, which is called damages." CAL. CIv. CoDE $\$ 3281$ (West 1970). "[In this section] the Legislature did not intend to expand our law of damages so as to include within its scope attorney fees." Woodward v. Bruner, 104 Cal. App. 2d 83, 86, 230 P.2d 861, 862 (2d Dist. 1951). "[I]t is improper to include attorney's fees as a part of exemplary damages." Viner v. Untrecht, $26 \mathrm{Cal}$. 2d 261, 273, 158 P.2d 3, 9 (1945).

29. In Isthmian Lines, Inc. v. Schirmer Stevedoring Co., 255 Cal. App. 2d 607, 63 Cal. Rptr. 458 (1st Dist. 1967), Prentice was invoked by a shipowner who was codefendant in a personal injury action. At trial, the shipowner had recovered his attorney fees from the equipment company whose defective forklift had actually injured the plaintiff. Reversing the fee award, the First District held that these facts did not fall within the "limited class of cases" covered by Prentice. Unfortunately, the court chose to define this class to include cases in which attorney fees "constituted" the damage caused by the tortfeasor. Attorney fees in all tort litigation might fit this rubric, since a natural consequence of most torts is that the injured party will incur attorney fees in trying to gain compensation for damages suffered. In all likelihood, however, Isthmian meant to hold that the third party exception could be applied where attorney fees constituted the only damage caused by the tortfeasor. Such a rule might be justified on the ground that an award of attorney fees in such situations would have a deterrent effect on wrongdoers. It would, however, provide little comfort to plaintiffs, whose need to recover attorney fees is surely more urgent where such fees constitute merely a part, rather than all, of the damage they have suffered. Moreover, while such a holding would be consistent with the facts in Prentice (where plaintiff Prentice sought and recovered only attorney fees from the escrow agent tortfeasor), it is inconsistent with the facts of Isthmian itself, since the only loss ultimately inflicted on plaintiff was the attorney fees it was forced to pay.

30. Banville v. Schmidt, 37 Cal. App. 3d 92, 106, 112 Cal. Rptr. 126, 135 (3d Dist. 1974); Lang v. Klinger, 34 Cal. App. 3d 987, 993, 110 Cal. Rptr. 532, 535 (1st Dist. 1973); Hunt v. 
however, a panel of the First District, with little discussion or analysis, applied Prentice outside the arena of title actions. ${ }^{31}$ Shortly thereafter, a Third District opinion sharply declined the opportunity to follow suit, fearing that a broad application of the third party exception would "open a Pandora's Box." 32 The court, however, was unable to provide a convincing basis for limiting the broad language in Prentice. ${ }^{33}$ Recently, decisions in three different appellate districts have evinced a willingness to apply the

Smyth, 25 Cal. App. 3d 807, 836, 101 Cal. Rptr. 4, 23 (1st Dist. 1972); Moe v. Transamerica Title Ins. Co., 21 Cal. App. 3d 289, 303, 98 Cal. Rptr. 547, 556 (1st Dist. 1971); Glass v. Gulf Oil Corp., 12 Cal. App. 3d 412, 438, 89 Cal. Rptr. 514, 532 (1st Dist. 1970); Northwestern Security Co. v. Flack, 6 Cal. App. 3d 134, 145-46, 85 Cal. Rptr. 693, 700 (1st Dist. 1970); Cook v. Redwood Empire Title Co., 275 Cal. App. 2d 452, 454, 79 Cal. Rptr. 888, 889 (1st Dist. 1969); Ruth v. Lytton Sav. \& Loan Ass'n, 266 Cal. App. 2d 831, 845, 72 Cal. Rtpr. 521 , 530 (1st Dist. 1968). But cf. Peter Kiewit Son's Co. v. Summit Constr. Co., 422 F.2d 242, 275 (8th Cir. 1969) (Prentice not applicable to contract action); Goodman v. Severin, 274 Cal. App. 2d 885, 896, 79 Cal. Rptr. 555, 561-62 (2d Dist. 1969) (same).

Alternatively, some courts have cited Prentice for its general rule, rather than for its exception, treating it simply as another affirmation of the American rule. Maier Brewing Co. v. Fleischmann Distilling Corp., 359 F.2d.156, 159 n.3 (9th Cir. 1966); Jensen v. Dalton, 9 Cal. App. 3d 654, 658, 88 Cal. Rptr. 426, 428 (1st Dist. 1970); Bay Shore Homes, Inc. v. San Diego Trust \& Sav. Bank, 276 Cal. App. 2d 108, 117, 80 Cal. Rptr. 849, 856 (4th Dist. 1969); Carroll v. Hanover Ins. Co., 266 Cal. App. 2d 47, 50, 71 Cal. Rptr. 868, 870 (1st Dist. 1968).

31. Vanguard Recording Soc'y, Inc. v. Fantasy Records, Inc., 24 Cal. App. 3d 410, 100 Cal. Rptr. 826 (1st Dist. 1972). Vanguard had previously sued Fantasy and various third parties to enjoin the sale of an unauthorized recording; it then recovered attorney fees incurred in the prior suits. On appeal, the award was upheld under the Prentice exception because "the defendant's breach of duty to the plaintiff had made it necessary for the plaintiff to sue third persons . . . ." Id. at 419, 100 Cal. Rptr. at 832-33. See Pachmayr Gun Works, Inc. v. Olin Mathieson Chem. Corp., 502 F.2d 802, 810 (9th Cir. 1974).

32. Trails Trucking, Inc. v. Bendix-Westinghouse Air Brake Co., 32 Cal. App. 3d 519, 524, 108 Cal. Rptr. 30, 34 (3d Dist. 1973). A truck belonging to Trails had struck an automobile when the brakes on the truck failed. In the ensuing litigation, Trails joined the supplier of the brake hose, claiming that the accident was due to a defect in the part supplied. A jury found the supplier solely liable, and Trails cited Prentice to support a further claim against the supplier for attorney fees. In a separate proceeding, the trial court directed a verdict against Trails on its claim for attorney fees.

The Third District Court of Appeal affirmed. It acknowledged a "superficial similarity" to Prentice in that the supplier's negligence was solely responsible for the accident and the suit against Trails. Prentice was nonetheless distinguished because the court found that, in the case at bar, the defendant's misconduct was not the "be-all and end-all of the litigation. At the outset, it was not the purpose of the litigation at all." Id. at 523, 108 Cal. Rptr. at 33.

33. The Court suggested that Prentice's "exceptional circumstances" required the presence of bad faith by the tortfeasor: "fraud, separate litigation necessarily brought about by the wrongdoing of the ultimate single tortfeasor, [or a] chain of vexatious litigation." 32 Cal. App. 3d 519, 524, 108 Cal. Rptr. 30, 34 (3d Dist. 1973). But there was no fraud in Prentice, nor chain of vexatious litigation, and insofar as there was "separate litigation necessarily brought about by the wrongdoing of the ultimate single tortfeasor," this describes Trails perfectly well-there having been a separate proceeding for fees. Moreover, the requirement of "separate litigation" has been denied by Ruth v. Lytton Sav. \& Loan Ass'n, 266 Cal. App. 2d 831, 845, 72 Cal. Rptr. 521, 537 (1st Dist. 1968), on grounds provided by Prentice itself: "there is no reason why recovery of such fees should be denied simply because the two causes . . . are tried in the same court at the same time." Prentice v. North American Title Guarantee Corp., 59 Cal. 2d 618, 621, 381 P.2d 645, 647, 30 Cal. Rptr. 821, 823 (1963). 
third party exception in personal injury, ${ }^{34}$ fraud, ${ }^{35}$ and declaratory judgment actions ${ }^{36}$ without discussion of earlier cases to the contrary and without any policy analysis. Such an expansion, if unchecked, could severely undermine the American rule; it is thus necessary to examine the impact of the exception on the policies underlying the American rule before deciding the proper scope of the third party exception.

\section{B. Proper Scope of the Third Party Exception}

Close analysis of the third party exception indicates that it may be consistent with many of the policies supporting the American rule. It would not discourage meritorious claims, since a successful claimant recovers attorney fees while an unsuccessful one does not have to pay the opponent's fees. Nor would the exception discourage meritorious defenses in the second suit against the actual tortfeasor, since it would not alter the rule that normally forbids fee shifting in two-party litigation. Finally, it could promote judicial economy if it encouraged the actual tortfeasor to come forward and defend the initial suit, thereby eliminating useless litigation between plaintiffs and innocent third parties.

On the other hand, fee awards would continue to be viewed by some as too remote to allow in most cases. ${ }^{37}$ The third party exception might also encourage plaintiffs to sue unnecessary parties in hopes of recovering their attorney fees ${ }^{38}$ since the presence of third parties is a prerequisite to such recovery. This would clog the judicial process and impose significant attorney fees on the innocent parties so joined. The third party exception might discourage some parties from settling once they realize that the settlement may be followed by litigation against others for attorney fees. To the extent that parties are confident of recovering their attorney fees, they may be less concerned about avoiding unnecessary legal expenses. Where all three parties are together in a single suit, courts will have administrative difficulties in allocating a claimant's litigation expenses between those that

34. Lareau v. Southern Pac. Transp. Co., 44 Cal. App. 3d 783, 118 Cal. Rptr. 837 (1st Dist. 1975) (dictum). See also Writers Guild of America, West, Inc. v. FCC, 423 F. Supp. 1064, 1159 n. 148 (C.D. Cal. 1976); Canadian Universal Ins. Co. v. Employers Surplus Lines Ins. Co., 325 So. 2d 29 (Fla. App. 1976).

35. Glendale Fed. Sav. \& Loan Ass'n v. Marina View Heights Dev., Inc., 66 Cal. App. 3d 101, 135 Cal. Rptr. 802 (4th Dist. 1977).

36. Roberts v. Ball, Hunt, Hart, Brown \& Baerwitz, 57 Cal. App. 3d 104, 128 Cal. Rptr. 901 (2d Dist. 1976).

37. Discovery costs, for example, depend on the complexity of the evidence to be sifted rather than the character of the underlying tort; the policies that militate against fee awards in ordinary two-party suits therefore apply with even more force when the burden is to be laid on a third party who has no control over the litigation.

38. A plaintiff may know that defendant $A$ is the actual tortfeasor, but may include $B$ in the litigation in the hope of allocating a portion of the litigation costs, such as the depositions of certain witnesses or the preparation of expert testimony, to the litigation against $B$, thus enabling him to recover them from $A$ under the third party exception. 
are recoverable third party fees and those that are unrecoverable two-party costs.

A more fundamental restriction on the development of the third party exception may arise from statutory provisions. A broad exception would run directly counter to section 1021 of the Code of Civil Procedure, which forbids fee awards absent an enabling statute or an agreement by the parties. ${ }^{39}$ Provisions like this one are part of a comprehensive scheme to regulate, rather than to prohibit, the award of attorney fees. Increasingly in recent years, legislatures have been using selective allowance of attorney fees to advance specific public policies. Some courts, including the United States Supreme Court, have responded by curtailing expansion of the judicial power to award attorney fees in order to avoid intruding into the legislative arena. ${ }^{40}$ The California Supreme Court, for one, has resisted this trend to an extent, insisting that "the fashioning of equitable exceptions to the statutory rule to be applied in California is a matter within the sole competence of this court." 41 Nonetheless, it is likely that even the California Supreme Court will be reluctant to grant an across-the-board allowance of attorney fees in all third party situations, for, given the frequency with which third party litigation occurs in cases of negligent torts, such a broad exception would entirely undercut the legislative scheme. The court may be more likely to make a case-by-case analysis and to look for situations with "exceptional circumstances",42 that justify expansion of the third party exception to the American rule.

In searching for situations that may persuade a court to apply the third party exception, the brightest prospects seem to be in the area of intentional torts. An intentional tortfeasor can more easily be said to have foreseen the possibility of litigation and the resulting attorney fees, thus reducing concerns over remote damages. In many cases, intentional tortfeasors could eliminate unnecessary litigation against innocent parties by coming forward and assuming the litigation burden; failure to do so can be equated with the bad faith litigation tactics where attorney fees are traditionally allowed. ${ }^{43} \mathrm{In}$ such situations, the imbalance in the equities between the parties justifies calling forth an equitable exception to the statutory rule against fee awards.

39. Cal. Civ. Proc. CODE \& 1021 (West 1955), quoted in relevant part at note 6 supra.

40. Alyeska Pipeline Serv. Co. v. Wilderness Soc'y, 421 U.S. 240 (1975); see notc 12 supra.

41. Serrano v. Pricst (Serrano III), 20 Cal. 3d 25, 43, 569 P.2d 1303, 1313, 141 Cal. Rptr. 315,324 (1977).

42. The phrase does not appear in Code of Civil Procedure $\$ 1021$, but rather was introduced by the Prentice court.

43. Trails Trucking, Inc. v. Bendix-Westinghouse Air Brake Co., 32 Cal. App. 3d 519, 108 Cal. Rptr. 30 (3d Dist. 1973), discussed in note 31 supra, rejected the existence of any duty regarding fees, stating: "Bendix had owed a duty to Trails not to damage its truck negligently. For the breach of that duty the damage was fixed and tendered by Bendix. It does not follow that a duty arose owed by Bendix to defendant Trails to pay attorney's fees incurred by Trails . . . "Id. at 524, 108 Cal. Rptr. at 34. 
Finally, allowing fee awards against such tortfeasors should act as an added deterrent to intentional wrongdoing. ${ }^{44}$

Courts might also consider extending the third party exception to those areas where an award of attorney fees is the only liability that can be imposed on a tortfeasor, ${ }^{45}$ as often happens where the plaintiff seeks only injunctive or declaratory relief ${ }^{46}$ or, as in Prentice, seeks only to quiet title to property. In many such situations, fee awards would provide a necessary deterrent to misconduct, especially if the tortfeasor otherwise escapes involvement in the litigation because the equitable relief must be sought from third parties. In Prentice itself, the court may have awarded attorney fees to provide just that deterrence, and the language about fees being damages may have been aimed at situations where attorney fees are the only damages for which the tortfeasor can be held liable. ${ }^{47}$

Courts should, however, be hesitant about extending the third party exception to the large number of cases in which a plaintiff is able to recover compensatory damages from a tortfeasor who is only negligent. ${ }^{48}$ Damage awards alone should provide adequate deterrence against negligent misconduct in those cases. Fee awards in such cases are a less foreseeable and

44. Strict liability presents a different situation, since an award of attorney fees will be based on express or implied warranty or indemnity. The rule in California is that indemnified parties will be able to recover both their portion of the judgment and attorney fees incurred in defense of the action. Raynolds v. Volkswagenwerk Aktiengesellschaft, 275 Cal. App. 2d 997, 1006, 80 Cal. Rptr. 610, 616 (1st Dist. 1969). See also Davis v. Air Technical Indus., Inc., 67 Cal. App. 3d 701,136 Cal. Rptr. 801 (2d Dist. 1977). This, in turn, is "an agreement, express or implied, of the parties" exempt from the limitations of Civil Procedure Code $\S 1021$, and subject to different rules and policies than is the third party exception. See generally nnot., 4 A.L.R. 3d 270 (1965).

45. See note 28 supra.

46. See Petition of State Farm Mut. Auto. Ins. Co., 212 N.W.2d 821, 50 Mich. App. 71 (1973) (third party exception allowed in declaratory relief action).

47. Assuming the third party exception is allowed, another problem is determining which parties should be entitled to the benefit of it. Where plaintiff is forced to sue parties $A$ and $B$ because of the misconduct of $B$, plaintiff certainly falls within the wording of the third party exception. If, however, $A$ is free from fault and is forced to incur attorney fees only because of $B$ 's tortious conduct, $A$ would also have a claim against $B$ for recovery of such costs. If $A$ is guilty only of passive negligence and is entitled to indemnity from $B$, existing exceptions to the American rule enable $A$ to recover attorney fees. On the other hand, if $A$ is found to be actively at fault, $A$ 's attorney fees can no longer be viewed as having been required because of "the tort of another," and $A$ would not appear entitled to any fee award from $B$. In such cases, plaintiff's suit against $A$ would be due to $A$ 's misconduct, not $B$ 's, and plaintiff should also be denied any recovery for attorney fees, unless perhaps $B$ is an intentional tortfeasor or would otherwise escape liability altogether.

48. Of the majority of jurisdictions that now allow some version of the third party exception, see note 17 supra, California alone has applied it in the case of a negligent tort other than one in the area of quiet title. Commentators occasionally assert the contrary. For example, I SPEISER, supra note 7, indicates that fees may be awarded where the underlying tort is a negligent act ( $\$ 13: 4$, at $625 \mathrm{n} .36$ ) or "inadvertent" ( $\$ 13: 4$, at $626 \mathrm{n}$. 42). The cases cited in support, however, all involve breach of contract rather than tort. As in California, where Code of Civil Procedure $\$ 1021$ allows fee awards in the case of an express or implied agreement, so in other jurisdictions contract actions are subject to different rules than tort actions with regard to fee awards. See generally Annot., 4 A.L.R. 3d 270 (1965). 
therefore more remote consequence of the tortfeasor's conduct than is the direct harm for which recovery is traditionally allowed. Since many negligent tortfeasors in multiple party situations are uncertain of their liability until the jury verdict is returned, it cannot be said that they have acted in bad faith in failing to come forward and assume the litigation burden of the innocent third party. Lacking such bad faith, the equitable pressure for judicial intervention is lessened. Finally, several rules governing compensatory damages, such as those involving collateral source income and recovery for pain and suffering, have been justified in part as offsets against the burden of uncompensated attorney fees. Given such interaction among the elements of compensatory damages, large scale alteration of fee awards can be better accomplished by comprehensive legislative action than by piecemeal judicial intervention.

\section{CONCLUSION}

The Prentice exception would allow recovery of attorney fees from a tortfeasor to the extent that the tortfeasor caused another to bring or defend an action against a third party. This exception, if not further qualified, might undermine policies that, in America, require litigants to bear their own attorney fees. To prevent this result while retaining the potential advantages of the Prentice exception, courts should allow recovery of fees only in exceptional circumstances, as with an intentional tortfeasor or where the tortfeasor would otherwise escape liability altogether. Any more comprehensive restructuring of the American rule regarding fee awards in negligence cases should be left to the legislature, in order both to protect existing legislative schemes and to avoid the hazards of piecemeal reform.

Barry Jablon *

\footnotetext{
* A.B. 1960, Columbia University; M.A. 1961, Ph.D. 1967, University of California, Berkeley; third-year student, Boalt Hall School of Law; Managing Editor, California Law Review.
} 